\title{
IAMJ
}

INTERNATIONAL

AYURVEDIC

MEDICAL JOURNAL

Case Report

ISSN: 23205091

Impact Factor: 5.344

\section{AYURVEDIC MANAGEMENT OF RAKTAPRADARA W.S.R. TO ENDOMETRIAL HYPERPLASIA - A CASE STUDY}

\author{
Bhavna Tripathi ${ }^{1}$, Pragyan Tripathi' ${ }^{2}$, Sunita D. Ram $^{3}$ \\ ${ }^{1}$ MD Scholar, PG Dept. Of Dravyaguna, Govt. (Auto.) Dhanvantari Ayurveda College and Hospital, Ujjain, \\ Madhya Pradesh, India \\ ${ }^{2} \mathrm{MD}$ at Narmade Ayurvedam Panchakarma Kendra, Ujjain, Madhya Pradesh, India \\ ${ }^{3}$ Reader \& HOD, PG Dept. Of Dravyaguna, Govt. (Auto.) Dhanvantari Ayurveda College and Hospital, \\ Ujjain, Madhya Pradesh, India
}

Corresponding Author: bhavnadubey54@gmail.com

https://doi.org/10.46607/iamj14p4052020

(Published online: July 2020)

Open Access

(C) International Ayurvedic Medical Journal, India 2020

Article Received: 26/06/2020 - Peer Reviewed: 24/07/2020 - Accepted for Publication: 31/07/2020

Check for updates

\begin{abstract}
Background: Ayurveda got incarnated upon the planet Earth to achieve the good health, which is prime root to perform virtuous acts, to acquire gratification of desires and last but not the least Emancipation. Now adays women are suffering from several gyneacological problems due to their unhealthy diet and lifestyle but most of the time they ignore their problems, and one of them most of the common problem is Raktapradara; which is characterized by irregular and/or excessive bleeding per vagina, caused not only during menses but may be even during intermenstrual period.

Material \& Method: A 47year old, married, female patient suffering from heavy vaginal bleeding which is previously diagnosed with Endometrial Hyperplasia in her USG findings, has given Shaman Chikitsa (Pittashamak, Vatashamak and Raktastambhak) and Shodhan Chikitsa (nitya virechan) for 3 months.
\end{abstract}

Conclusion: Treatment given to the patient proved very beneficial and quickly acting in the management of Raktapradara.

Keywords: Ayurveda, Raktapradara, Endometrial Hyperplasia, Shaman Chikitsa 


\section{INTRODUCTION}

Normal menstrual bleeding is cyclic, 3-5 days duration and 4 Anjali in Praman (approx. 50-60 ml.) with its normal colour (like Indragopa) as described in Ayurvedic texts. ${ }^{1}$ But when normal menstruation bleeding pattern is altered in reference of duration, amount, colour and cycle; the conditions are called Artavadushti and Raktapradara is one of them. In Raktapradara excessive and irregular bleeding occurs per vagina during menses or intermenstrual period. ${ }^{2}$ Raktapradara is caused by excessive consumption of salty, sour, heavy, Katu, Vidahi and unctuous substances, meat of domestic, aquatic and fatty animals, Krasara, Payasa, curd, Sukta, Mastu and wine. ${ }^{3}$ Endometrial Hyperplasia is a condition in which the endometrium becomes abnormally thick. Although endometrial hyperplasia is not cancer, it can lead to uterine cancer in some women. It is characterized by heavier or longer lasting menstrual bleeding than usual. It is usually caused by an excess of estrogen without progesterone. The progesterone is not made, and the lining of uterus does not shed of and ovulation does not occur. This means that the endometrium may continue to grow in response to the production of estrogen. The cells of the endometrium may abnormally crowd(hyperplasia) which may lead to the cancer of uterus. ${ }^{4,5,6}$

\section{Case Presentation}

A female patient aged 47 year, married, housewife, multigravida (G2, P2, A0, L2, D0) was examined in the center. In her previous USG report dated 22/1/2018 she was diagnosed with endometrial hyperplasia. Patient was complaining of continuous heavy bleeding (4-6 pads/day) and bleeding stopped only after intake of allopathic medication and restarts on stopping the medication and doctor had advised her to undergo hysterectomy surgery. Other associated complaints of patient were hyperacidity, chronic constipation, low back pain and lethargy. On examination patient was found aneamic and with abdominal distension. There was no any abnormal findings seen in the physical examination and in per vaginal examination uterus is bulky, no tenderness in fornices and fresh bleeding found.

\section{Treatment}

The treatment was carried out with the following medicines (table 1) for 3 months. During this period patient was advised to take Santarpan (milk) and Raktavardhak Ahara (seasonal fruits and green leafy vegetables) and was asked to prepare her meal in Iron utensils and to avoid, Vidahi, Snigdha, Lavan, Amla and Katu Ahara and avoid physical and mental exertion. After 3 months of treatment she was relieved from excessive bleeding and her periods reached normalcy, without any allopathic medication. Then patient was asked to undergo sonography. That sonography report dated on 15/5/2018 revealed no Endometrial Hyperplasia.

Table 1: Drugs prescribed to the patient

\begin{tabular}{|c|c|c|c|}
\hline Sr. No. & Name of the drugs & Quantity & Dosage \\
\hline 1. & $\begin{array}{l}\text { Pushyanug Churna } \\
\text { Bhuiamla Churna } \\
\text { Godanti Bhasma } \\
\text { Mandur Bhasma } \\
\text { Sphatika Bhasma }\end{array}$ & $\begin{array}{l}3 \mathrm{gm} \\
2 \mathrm{gm} \\
500 \mathrm{mg} \\
125 \mathrm{mg} \\
125 \mathrm{mg}\end{array}$ & $\begin{array}{l}\text { Twice a day with honey and Tan- } \\
\text { dulodak }\end{array}$ \\
\hline 2. & Dashmool Qwath & $20 \mathrm{ml}$ & Twice a day with jala \\
\hline 3. & Patrangasava & $20 \mathrm{ml}$ & Twice a day with Sambhaga jala \\
\hline 4. & Chandraprabha Vati & $500 \mathrm{mg}$ & Twice a day \\
\hline 5. & Shatavarex & $5 \mathrm{gm}$ & Twice a day with milk \\
\hline 6. & Erand Bhrist Haritaki & $2 \mathrm{gm}$ & At bedtime with lukewarm water \\
\hline
\end{tabular}

Observation \& Result: The patient had followed the Ahara \& Aushadhi instructions strictly. The sonography was made after 3 months. The findings of sonography report before and after treatment are as shown in Table 2. 
Table 2: Results of Sonography (Pelvis)

\begin{tabular}{|l|l|l|}
\hline Particulars & Before treatment (22/1/2018) & After treatment (15/5/2018) \\
\hline Uterus & Bulky, retroflexed and heterogenous myometrium & Normal, anteverted, homogenous walls \\
\hline Endometrium & Endometrium thickness is $18 \mathrm{~mm}$ & Endometrium thickness is 5mm \\
\hline Right Ovary & Normal in size & Normal in size \\
\hline Cul de sac & Normal in size & Normal in size \\
\hline
\end{tabular}

\section{DISCUSSION}

Endometrial Hyperplasia caused excessive vaginal bleeding which affects women's routine lifestyle. Medication which was given to the patient i.e. Pushyanug Churna cures Raktapradara, Yonidosha, Shwet, Neel, Peet, Krishna and Arun Pradara. Bhuiamla also a wellknown drug mentioned in Pradar Roga. ${ }^{7}$ Godanti bhasma is carrying Sheet Guna and also a calcium supplement ${ }^{8}$ and quick relief in Rakta Pradara when it gives along with Patrangasava. ${ }^{9}$ Sphatika bhasma acts as Raktasravarodhaka and Madhur, Kashaya with slight Amla in Rasa. Mandur bhasma is Sheet in Guna and Veerya, Vrishya and Param Raktavriddhikara (best haemetinic) in karma. ${ }^{10}$ Dashmool Qwath acts as Vatashamaka and in Charak Samhita it is mentioned that in any type of Yoniroga, Vatadosha is always dominant. ${ }^{11}$ Chandraprabha Vati acts on Pandu, Katishula, Striroga, Artava Ruja, Daurbalya and diseases of Artava in females. ${ }^{12}$ Patrangasava cures Raktapradara, Pandu, Dustartava and Daurbalya. Most of the ingredient of Patrangasava are having Sheet and Kashaya in Rasa. ${ }^{13}$ Shatavarex is a patent medicine in which Shatavari is main ingredient. It is madhur and tikta in rasa and sheet in Veerya and cures Vata, Pitta and Rakta Dosha and also cures various reproductive and hormonal issues in women. ${ }^{14}$ Erand Bhrista Haritaki was given as a mild purgative to relieves her constipation. It is also mentioned in Kashyap Samhita, purgation relieves Asrigdosha.

\section{CONCLUSION}

There are several formulations, lifestyle, diet is mentioned in various ayurvedic texts for the efficacious treatment of Raktapradara. This study is said to be an excellent example in the proper and effective management of Endometrial Hyperplasia/Raktapradara.

\section{REFERENCES}

1. Prof.(km.) Premvati Tewari, Ayurvedic Prasutitantra evam Striroga, Part I, Prasuti Tantra (Obstetrics), published by Chaukhambha Orientalia, Varanasi, reprint edition 2003, pg. 41,60,62,64

2. Prof.(km.) Premvati Tewari, Ayurvediya Prasutitantra evam Striroga Part II, Striroga (Gynecology), published by Chaukhambha Orientalia, Varanasi, reprint 2018, pg. 173

3. Prof.(km.) Premvati Tewari, Ayurvediya Prasutitantra evam Striroga Part II, Striroga (Gynecology), published by Chaukhambha Orientalia, Varanasi, reprint 2018, pg. 174

4. Dutta D.C., Textbook Of Gynecology Including Contraception, $5^{\text {th }}$ edition, published by New Central Book Agency(p)Ltd. Kolkata, reprint 2008, pg.181-191,317

5. https://my.clevelandclinic.org7health

6. https:familydoctor.org/condition/endometrialhyperplasia/

7. Kaviraja Shri Ambika dutt Shastri Ayurvedacharya, Bhaishajya Ratnawali, $16^{\text {th }}$ edition, published by Chaukhambha Sanskrit Sansthan, Varanasi, reprint 2002, pg. 717

8. Vaidya Yadavji Trikamji Acharya, Rasamritam, English translation by Dr. Damodar Joshi \& Dr. G. Prabhakar Rao, $2^{\text {nd }}$ edition, published by Chaukhambha Sanskrit Bhawan, Varanasi, 2003, pg.121

9. Ayurveda Saar Sangraha, published by Shri Vaidyanath Ayurveda Bhawan Limited, Naini, Allahabad, edition 2008, pg.101

10. Vaidya Yadavji Trikamji Acharya, Rasamritam, English translation by Dr. Damodar Joshi \& Dr. G. Prabhakar Rao, $2^{\text {nd }}$ edition, published by Chaukhambha Sanskrit Bhawan, Varanasi, 2003, pg.141 \& 95

11. Dr. Brahmanand Tripathi, Charak Samhita of Agnivesha, vol. II, elaborated by Charak Dradhabala edited with 'Charak Chandrika' Hindi commentary, published by Chaukhambha Surbharti Prakashan, Varanasi, reprint edition 2011, pg.1031 
12. Vaidya Yadavji Trikamji Acharya, Rasamritam, English translation by Dr. Damodar Joshi \& Dr. G. Prabhakar Rao, $2^{\text {nd }}$ edition, published by Chaukhambha Sanskrit Bhawan, Varanasi, 2003, pg.188

13. Ayurveda Saar Sangraha, published by Shri Vaidyanath Ayurveda Bhawan Limited, Naini, Allahabad, edition 2008, pg.650

14. Pizzorno Jr. Joseph E. Murray, Michael T., Joiner-Bey, Herb (2015), The Clinician's Handbook of Natural Medicine ( $3^{\text {rd }}$ ed.) Churchill Livingstone, pg.516

\section{Source of Support: Nil}

\section{Conflict of Interest: None Declared}

How to cite this URL: Bhavna Tripathi et al: Ayurvedic Management Of Raktapradara W.S.R. To Endometrial Hyperplasia - A Case Study. International Ayurvedic Medical Journal \{online\} 2020 \{cited July, 2020\} Available from: http://www.iamj.in/posts/images/upload/2446_2449.pdf 